\title{
Edge-Ground and Waisted Axes in the Western Pacific Islands: Implications for an Example from the Yaeyama Islands, Southernmost Japan
}

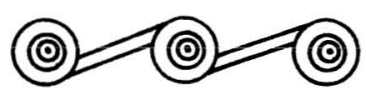

\section{ATHOLL ANDERSON AND GLENN SUMMERHAYES}

EDGE-GROUND AND WAISTED AXES have been recorded from various localities in the western Pacific, including Australia, Papua New Guinea, and Japan, where they occur in late Pleistocene sites. Whether they carry the same early chronological or functional significance in each area remains uncertain and later examples continued to be produced through the Holocene and up until the ethnographic present in some areas, but only sporadically in others. As this point suggests, broad similarities among hafted axe-like implements from Asia to Australia probably conceal rather complex local histories, although less the result of successive migration than of "parallel developments within the same technological tradition" (Golson 1974:549). One such development is the combination of edge-grinding and waisting within the same implement. We have discovered an example of this and seek to understand it. The example in question is an edge-ground, waisted axe from Iriomote Island, one of the Yaeyama group in the southern Ryukyu Islands of Japan. The artifact is apparently without parallel in that archipelago, and as the site offered no immediate means of obtaining a radiocarbon date or any other estimate of the age or cultural context of the artifact, and permission to excavate at the site has not been granted so far, we attempt here to set the Iriomote axe within some potential contexts of Yaeyama's prehistory through a review of the regional evidence. We conclude that the Iriomote axe has no parallel in Japan or Taiwan.

First, some matters of definition deserve comment. Early references to waisted implements used the term "waisted blade," but as Groube (1984:168) remarked, with few exceptions, "none of these tools was developed from blades struck from cores in the classic manner; few even resemble a blade." In common with other authorities he called them waisted axes. Yet, it could be argued that some of these tools do not exhibit the characteristic shape or edge of an axe, and may never have functioned in that capacity. Bulmer's research in Papua New Guinea

Atholl Anderson is Professor, Department of Archaeology and Natural History, Research School of Pacific and Asian Studies, Australian National University, Canberra; Glenn Summerhayes is Professor and Head, Department of Anthropology, University of Otago, Dunedin, New Zealand. 
(1977:50) showed that, "some of the waisted blades [are] relatively too thin and fragile to be used as striking implements, which is why the term 'waisted blade' was used in the first place." The terminology has been ambiguous, but waisted axe is used here to refer to the sub-group of butt-modified tools defined by Golson (2001: Fig. 1). There is a distinction between waisting, stemming, and tanging of axes or other implements, although the categories are blurred at the margins (Bulmer 1977; Golson 2001:187). Stone blanks of various forms, including blocks, blades, flakes, and pebbles have been waisted. Many of those otherwise unmodified probably functioned as line or net weights for fishing, loom weights, or in other capacities (see examples in Bellwood et al. 2003). We are concerned here primarily with edged tools and regard a bifacially symmetrical blade as distinguishing an axe from an adze. However, many flaked stone tools in Pleistocene contexts, including those with distinctly asymmetrical blades are often described as axes, as are many kinds of Neolithic and later adzes in much of the older western Pacific archaeological literature. It is beyond our aims to resolve these inconsistencies here and when referring to the literature we use the terms as given.

\section{THE IRIOMOTE ISLAND AXE}

The discovery occurred in 2005 during a survey of sites potentially of the Shimotabaru Phase on Iriomote Island (Fig. 1), as part of a project on the early colonization of islands to the south (Bellwood et al. 2003), and east (Summerhayes et al. in prep), of Taiwan. The site, called Nakano, lies on a gentle slope near the top of a hill, $39 \mathrm{~m}$ above sea level, at $24^{\circ} 25^{\prime} 57^{\prime \prime} \mathrm{N}, 123^{\circ} 46^{\prime} 57^{\prime \prime} \mathrm{E}$, about $0.7 \mathrm{~km}$ from the coast in broken hill country (Fig. 1). The axe was found lying flat, with one face exposed, on a compacted yellow-brown clay surface of a pineapple field from which the topsoil had been scoured by recent rain. Although it lay in a slight hol-

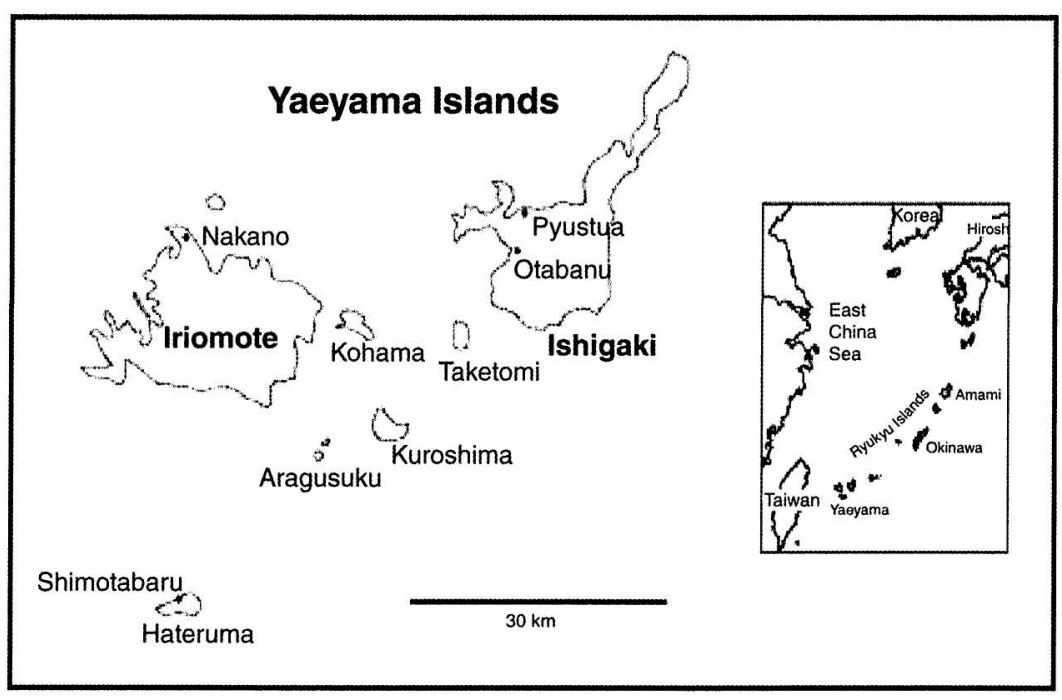

Fig. 1. The Yaeyama Islands, showing sites mentioned in the text. 
low of exactly the same size and shape, it was impossible to tell whether it had once lain enclosed within the clay, or was simply within a recent hollow in the ploughed soil above it. Inspection of the pineapple field surface disclosed some sherds of modern ceramics and, approximately $15 \mathrm{~m}$ away from the axe, a small flake of light grey chert.

The axe was carefully washed and examined in hand and by low-powered ( $\times 15)$ magnification. On the exposed surface of the axe there are several recent gouges, from ploughing. Otherwise the artifact is intact. It has a brown patina but, judging from some water-rolled cortex remaining on the butt, it was fashioned from a cobble of very dense, heavy, pale-green to gray schist, in which there occur olive phenocrysts up to $4 \mathrm{~mm}$ in maximum length. The axe weighs $785 \mathrm{~g}$. It is $133 \mathrm{~mm}$ long, $78 \mathrm{~mm}$ wide at the waist, and $86 \mathrm{~mm}$ and $93 \mathrm{~mm}$ at the maximum width of the butt and blade half respectively. The maximum thickness is $35 \mathrm{~mm}$ (Figs. 2, 3). As part of the fieldwork protocol, the artifact was given into the custody of Mr. Nakamori, the archaeologist for the Taketomi Board of Education, once it had been weighed, drawn, and photographed. There has been no opportunity yet to undertake a source analysis of the adze material.

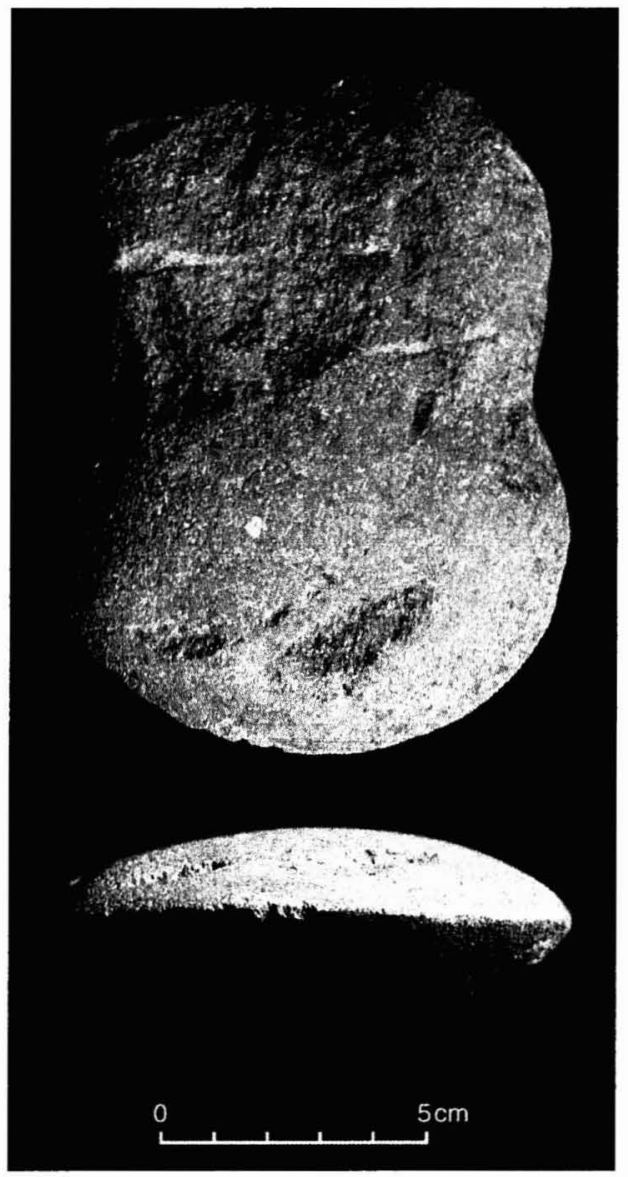

Fig. 2. The Iriomote axe, showing the upper surface, with recent ploughing scratches, as it lay on the ground, and the cutting edge, also with slight recent damage. 


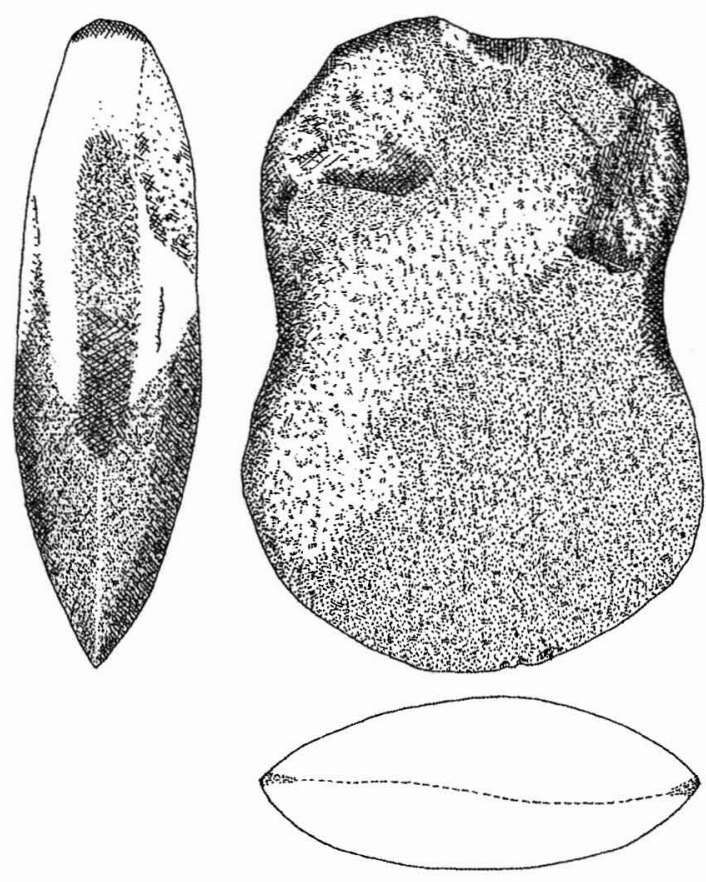

Fig. 3. The Iriomote axe, showing the lower surface and side and edge-on views. The lighter surface shading indicates patches of original water-rolled cortex, the darker shading, areas of grinding. Drawn by Peter Matthews.

The blade half of the artifact was finely ground on all surfaces to produce a sharp, curved edge. The waisting had been created by flaking and then some grinding. No hafting polish was observed. Signs of original flaking showed that the butt had been reduced in thickness by removal of large, hinged-fracture flakes. This may have been intended to produce a better balance in weight about the hafting point at the waist, with butt-reduction flaking compensating for the loss of material by grinding the blade. The butt half was also partly ground on the top and bottom surfaces.

One Ryukyuan colleague recalled that a similar tool was found in the early excavations at the Shimotabaru site (in fact, while from Hateruma island, the location of this artifact is unknown: Kanaseki et al. 1964: Pl. XV), but while that artifact is waisted, it has no shaped edge (Fig. 4). It is not an axe or an adze, and waisted, unground axes are "not known in the Yaeyama area" (Kokubu $1963: 229)$. The Hateruma implement, rounded at both ends, was probably used as a weight. No artifact similar to the Iriomote axe is illustrated in archaeological reports on the Shimatobaru Phase settlement in the Yaeyama Islands such as those on the sites of Shimotabaru on Hateruma (Kanaseki et al. 1964; Nishimura et al. 1960; Okinawa Prefectural Board 1986); Otabaru on Ishigaki (Ishigaki Town Education Board 1982); Pyutsuta on Ishigaki (Ishigaki Town Education Board 1997); and the Soedo site on Tarama Island (Okinawa Prefectural Tarama-village Education Board 1996). No similar axe was excavated from sites of any other period from any of the Yaeyama archaeological sites. Furthermore, with the exception of an example given above, none of the local archaeologists could recall the existence of a similar artifact in the islands. Naoichi Kokubu $(1963: 227)$ said that "at Shimotabaru, stone axes with ground or half-ground edges prevailed and 


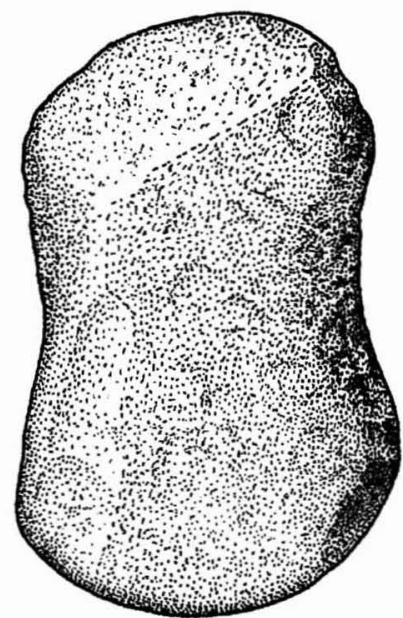

0

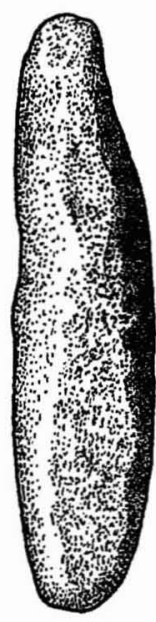

Fig. 4. Waisted implement from Hateruma island, unknown location, held in the Kyushu University Museum, Gyokusenkan (after Kanaseki et al. 1964: Pl. XV).

were presumably farming implements," and that "this kind of stone implement appeared at Nakama shell-mound no. 1 [Iriomote Island] before the appearance of pottery." He was writing at a time when axe often included adze and when pottery was thought to have arrived only about A.D. 1000 in the Yaeyamas. Subsequent research has shown that pottery and probably agriculture arrived with the earliest known colonists (Shimotabaru phase) about 3800 B.P. (Ohama 1999, 2002; Summerhayes et al. in prep.), and later excavations at the type site on Hateruma Island show that there were no polished stone, waisted axes. Narrow adzes of fine-grained volcanic rocks, especially of a green-tinged basalt that was quarried from the east coast of Iriomote (part of the Tomuru geological formation) are common in Shimatobaru sites. They are flaked, often fairly rudimentarily, and have the cutting edge asymmetrically beveled and ground. None of them resemble the Iriomote axe. Consequently, the edge-ground, axe-like form and waisting of the latter elicited comments from archaeologists in the Ryukyus to whom it was shown, not about the local archaeology, but rather about similar features in early mainland Japanese sites. We also thought that there might be some relationship to similar features in Australia and New Guinea. Yet, as neither we nor our Japanese colleagues could point to precise similarities, questions arise about the extent to which the salient features of the Iriomote axe can be invested with some wider meaning in regional prehistory.

\section{EDGE-GRINDING AND WAISTING IN THE WESTERN PACIFIC}

Two of the important features of technological prehistory worldwide are the development of edge-grinding to create a sharp and even cutting edge, and of hafting to assist the secure attachment of a handle. Edge-ground stone tools go back to about 20,000 years ago in the Yenisei valley of Siberia (Oda and Keally 1973:19) and in South China (Zhao et al. 2004), and both hafted and edgeground tools are of comparable or greater age in the western Pacific. 


\section{Near Oceania}

As Golson (2001:186) remarked, while late Pleistocene flake industries are unspecialized, and to that extent not remarkably different between Sunda and Sahul,

what is distinctive about the Sahul industries is the occurrence of axes or hatchets with edge grinding; of large 'waisted' tools indented at the sides presumably for hafting; and of implements where hafting aids are found together with edge grinding on the same piece.

Hafted, edge-ground axes were made until recently in traditional Aboriginal communities (Hayden 1979), but early examples (>5000 B.P.) are restricted to northern Australia. Edge-ground axe heads, generally of oval plan-shape, occur in Arnhem Land sites, such as Malangangerr, Level 111, and Nawamoyn, Level III, dated up to 23,000 B.P. (Schrire 1982:107-109). There are fragments dated to 28,000 B.P. in the Kimberley (O'Connor 1999:75) and up to 32,000 B.P. on Cape York Peninsula (Morwood and Tresize 1989). Grooving is the most common hafting feature, but one of the early Malangangerr examples is indented on one side (Schrire 1982:106), and an edge-ground axe from Level III at Nawamoyn, dated about 18,000-24,000 B.P., does appear to be slightly waisted (Schrire 1982: Fig. 42a). Waisted blades without edge-grinding occur on Kangaroo Island, South Australia. Lampert (1975) regarded them as being older than 10,000 B.P., the approximate date of insularization by eustatic sea level rise, and possibly as older than 16,000 B.P. He argued that the Kangaroo Island waisted blades were similar to tools from Queensland and eastern New South Wales known as MacKay hammerstones (McCarthy 1967); both are bifacially flaked, waisted, and unground.

In New Guinea, unground waisted blades are associated with early levels of the site at Kosipe (White et al. 1970), where they have been found in contexts dated to 26,000 B.P. Recent research has produced more examples (Fig. 5) and shown that they can be dated to as early as 35,000 B.P. (Fairbairn et al. 2006). The Bobongara site, Huon Terraces in northeast Papua New Guinea, is another important locality for unground, waisted blades. More than 100 have been recovered and uranium-thorium dating of tephras on the terraces indicates that the age of some waisted blades may exceed 40,000 B.P. (Bulmer 2005:396; Groube 1989; Groube et al. 1986). Several similar waisted axes are reported from the Solomons (Golson 2001: 195).

Fragments of edge-ground axes have been recorded from Kafiavana Rockshelter in Papua New Guinea, dating to about 11,000 B.P. and possible edge-ground artifacts dating to about the LGM at Kosipe (Golson 2001 : 196). An edge-ground axe, without butt modification, dates to about 25,000 B.P. at Nombe (Golson $2001: 201)$. Several broken artifacts and fragments, possibly from waisted axes or their preforms, date 9000-6000 B.P. at Kiowa Rockshelter (Bulmer 2005:399400). At Yuku Rockshelter, unground waisted axes are probably of late Pleistocene age (Golson 2001:194), extending perhaps to about 18,000 B.P. (Bulmer $2005: 392$ ). In short, there is no clear record of butt-modified (including waisted) edge-ground tools in Pleistocene New Guinea (Golson 2005 : 451), and the larger waisted, unground, axes of Bulmer's types 1a and 1b (2005:409) disappear in Highland New Guinea with the onset of the Holocene, the youngest at Yuku 

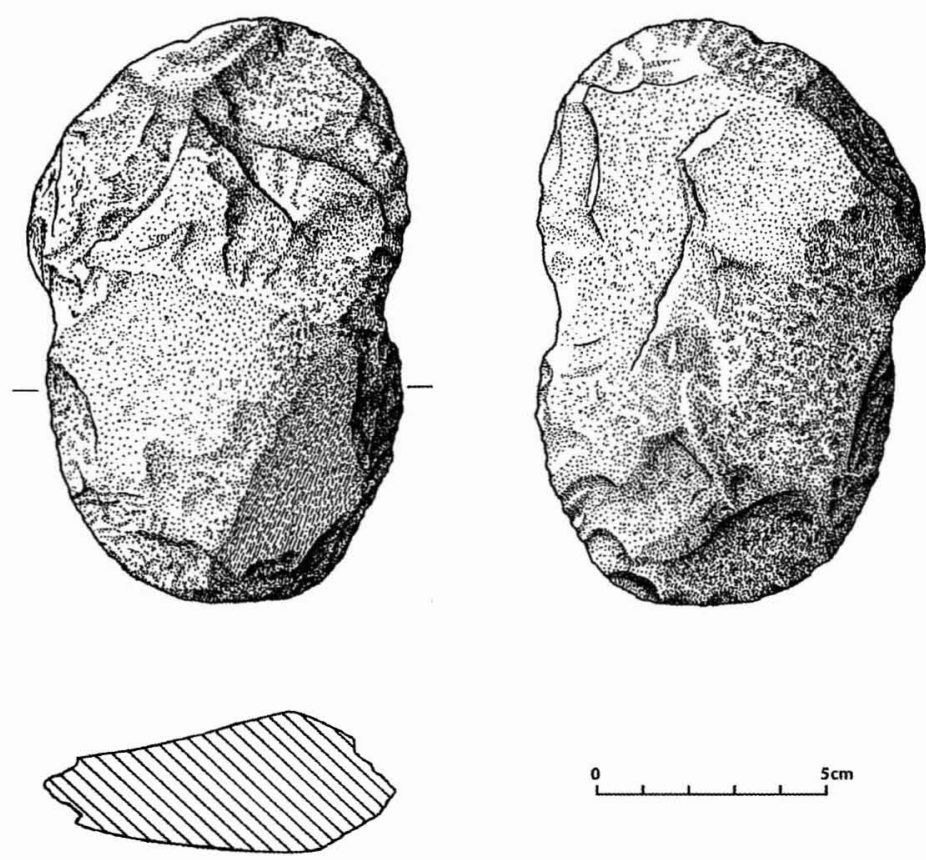

Fig. 5. An unground waisted blade from Kosipe, Papua New Guinea, recovered from 30 k-year-old layers. Drawn by Les O'Neill, Department of Anthropology, Otago University.

dates to about 11,000 B.P. (Bulmer 2005 : 442). However, small, possibly ornamental, edge- and surface-ground, waisted axes occurred in the early Holocene at Yuku. One is dated to about 5700 B.P., but may be from a disturbed context. Two others date 8300 B.P. and possibly 9500 B.P. (Bulmer 2005 : 408). The oldest example of an edge-ground, waisted axe in the New Guinea region appears to be an example from a level dated about 11,500 B.P. at Pamwak, Manus Island (Bulmer $2005: 402$ ).

\section{Southeast Asia and Japan}

There are edge-ground, axe-adzes at Niah Cave which probably date to the late Pleistocene, 15,000-20,000 B.P. (Golson 1974:543, 2001:186), and edgegrinding is dated to 18,000 B.P. in Viet Nam (Bellwood 1997:161) and, on shell artifacts, to 12,000 B.P. in the Moluccas (Bellwood 1997:187).

Edge-ground, flaked stone tools occur throughout Japan, although predominantly in the eastern region, dated to around 25,000 B.P. (Serizawa 1986:193), and especially in the Musashino Uplands, Honshu. Here, in the Tachikawa Loam, strata IX and X have produced edge-ground axes or adzes at various sites, sometimes in association with long flakes or blades. At the Kurihara site, dating approximately 28,000-29,000 B.P., there was one edge-ground pebble tool (Oda and Keally 1973:8); another, dated to about 30,000 B.P., was recovered from the Narita Airport site (Ikawa-Smith 1986:204), and similar tools are dated to 27,000 B.P. at the Susuki site (Inada 1987:10). Okamura (1992:29) has "partly-polished 
and chipped stone axes" dating to his Late Palaeolithic Culture, Phase 1, 32,00030,000 B.P. However, while edge-grinding seems to be an innovation dating to about that period, it was applied to "heavy-duty flake and pebble tools" (Oda and Keally 1973:3) which also occur without edge-grinding and have an antiquity extending to 35,000 в.P. Edge-grinding was initially unifacial, often applied to an edge of the flaked ventral surface of a split cobble, and it became more commonly bifacial by the terminal Pleistocene (Oda and Keally 1973:10-12). In Japan, edge-ground axes and adzes are unwaisted. Edge-grinding declined substantially after about 22,000 B.P. in Japan but it revived in the form of large, edge-ground and often beveled tools around 12,000-13,000 B.P. (Ikawa-Smith $1986: 205)$, a trend which also seems to be reflected in edge-grinding associated with the later Hoabinhian complex (Bellwood 1997:161) and with the Jomon, in which pebble and chopper tools are common throughout, but exhibit ground edges in some later examples (Esaka 1986:227).

Unground, bifacially flaked tools are typical of the Hoabinhian, dating from the late Pleistocene into the mid-Holocene, or even later. Some of these tools show incipient waisting, as at Gua Cha, Malaysia, where they occur in early Holocene levels (Bellwood 1997:159, 163). Leach (1938:161) recorded unground, waisted axes on Lanyu Island (Botel Tobago, Taiwan) the best of which, local Yami informants said, were dug out of the ground. As Leach (1938:163) went on to remark, "if any attempt were made to assess the general level of Yami culture purely on the basis of their methods of working stone, it is obvious that the most fantastically misleading deductions would necessarily result." The Lanyu waisted axes are thought to be about 2000 years old (Shi et al. 2001). Elsewhere in eastern Taiwan, unground, waisted axes are common in the artifactual assemblages of sites spanning the period 3500-1500 B.P., as at Beinan, 3500-2500 B.P. (Sung and Lien 2004), and Shanzongliao, about 2000 B.P. (Shi et al. 2001).

Whether waisting was necessarily for hafting has been questioned by Bulmer (1977:54). She notes that while some waists were polished in a manner suggestive of hafting, others appeared to have been used as concave scrapers. That observation raises a more general issue about the functions of these tools. Bulmer (1977:42-45) argued that some waisted axes in Papua New Guinea could have been used for digging and that they were not as useful as edge-ground axes for chopping. In fact some have such unformed ends as to be quite improbable as axes. Others may have been used to break into hollow trees when hunting possums, thin out Pandanus stands, process sago palms, etc. (Bulmer 2005:411; Groube 1989). Local informants told Bulmer (1977) that modern flaked-stone artifacts of similar form, although not waisted, were used to clear grass. Bellwood (1997:162) suggested that Hoabinhian pebble tools were used for vegetation clearance and ring-barking, recalling an earlier view by Groube (1989) about the Papua New Guinea waisted axes. Waisted axe or adze-like implements have long been assumed to have been used as hoes in Taiwan and adjacent islands such as Lanyu. Flaked stone axes, some waisted, which occurred commonly in the Middle Jomon, about 4000-5000 B.P. in eastern Japan, and in Late Jomon in western Japan, about 3000-4000 B.P., are thought to have been used to dig up native tubers, including yams (Imamura 1996:108).

The technological history, outlined above, shows that edge-grinding and 
waisting both have considerable antiquity in the western Pacific, but that they also occur into very recent times. The combination of edge-grinding and waisting continued into the recent era in the Solomons and waisted axes are said to have evolved into the fine, polished, examples of late Holocene and modern Papua New Guinea (Bulmer 1977:40). In northern Taiwan, at Yuenshan Site 2, about 3500-2500 B.P. (National Museum of Prehistory 2004), a stemmed and ground axe also has some slight waisting ground into it. Although most of these examples were thin, flat-bladed axes, quite unlike the Iriomote example, the basic techniques of waisting and grinding evidently persisted.

\section{SCENARIOS FOR THE IRIOMOTE AXE}

The technological and chronological data above, do not imply anything conclusive about the Iriomote example, but rather suggest some possibilities. Edgegrinding has a Pleistocene prehistory in Japan, becoming prominent from the terminal Pleistocene, but waisting seems to occur only on unground implements from mid- to late Holocene sites in Taiwan and Japan. As ground, waisted axes do not occur outside northern Australia earlier than in sites of the PleistoceneHolocene transition, it is unlikely that the Iriomote axe is of Pleistocene age. Broad-bladed axes, of the Iriomote plan shape, do tend to be earlier than narrow examples, but axes with grinding beyond their cutting edge tend to be relatively later than exclusively edge-ground examples.

Another approach to the question of where to locate the Iriomote axe chronologically is to consider when it might have been most easily deposited in the Yaeyamas from the terminal Pleistocene onward. The history of Quaternary land bridges in the region is unclear. A connection, or near connection, from mainland China (including at that stage Taiwan), to Okinawa via a Ryukyuan land bridge is hypothesized at 25,000-18,000 B.P. on the basis of mainland fauna in Okinawan Palaeolithic sites, which, unfortunately, contain no stone tools (Kimura 2000; Otsuka and Takahashi 2000). The Iriomote cat (Felis iriomotensis), still extant, and some fossil deer (Cervus astylodon) occur in the Yaeyamas and are probably of Middle Pleistocene origin, but various terrestrial fauna from pig (Sus leucomytax taiwanus) to mole (Apodemus agrarius), and plant taxa such as Titanotrichum oldami seem to have migrated into the central and southern Ryukyus from Taiwan or China during the last glacial era (Foster 1956:57; Motokawa 2000; Ujiie and Ujiie 1999; Wang et al. 2004). Sea level decline of 120-140 m exposed land bridges between China and Taiwan, where the average depth is $100 \mathrm{~m}$, and greatly reduced the sea gap from Taiwan to the Yaeyamas, if not actually closing it. Today, the sea is up to $800 \mathrm{~m}$ deep in that area, but some authorities attribute this to early Holocene crustal movement, arguing that the Kuroshio Current, which runs today through the southern Ryukyus, was deflected out to the east of them until after 10,000 B.P. (e.g., Ujiie and Ujiie 1999). One possibility, then, is that the Iriomote axe represents a terminal Pleistocene to early Holocene settlement of the Yaeyama Islands, which is not otherwise documented in current archaeological evidence.

A second possibility is that the Iriomote axe is a polished form of a Jomon waisted axe. There are early Jomon sites in Okinawa, one of them (Uhudobaru Shellmound) recently dated to about 6500 B.P. (Hiroki Miyagi, pers. comm.; 
Nakijin Town Educational Board, March 2006), and another, Noguni Shellmound, to 7000-6000 B.P. (Ito 2003). By that stage, seafaring technology in Japan may have been able to support voyages across the Kerama gap (Miyako Island to Kerama Island). However, direct evidence is lacking, and there is no other reason to think that Early or Middle Jomon colonists (c. 7000-4000 B.P.) reached the southern Ryukyus.

A third possibility is that the Iriomote implement is the first to be discovered of a type of axe which was used more or less exclusively in the inland hill country of the Yaeyamas at some stage during the known span of prehistory. Ujiie and Ujiie (1999) argue that there was another partial closure of the Taiwan-southern Ryukyus passage of the Kuroshio Current 4500-3000 B.P. This might have created conditions that favoured the currently known initial colonization of the Yaeyamas about 3800 B.P. Yet, relating the Iriomote axe to that event, and to the Shimotabaru colonizing phase, seems rather less likely than alternatives because the ground, waisted axe does not occur in known Shimotabaru sites. In addition, much of the coastal hinterland has been disturbed by agriculture and construction over many decades, and resulting surface collections are extensive. Artifacts as large and distinctive as the Iriomote axe are difficult to overlook. Had they been at all common it could be expected that by now they would be represented in the collections or literature.

A fourth, and rather more speculative possibility, is that the Iriomote axe represents an early passage northward from Near Oceania. While the history of west Pacific seafaring remains uncertain, one point is generally agreed, which is that by the terminal Pleistocene there had been open-sea passages out of sight of land, and of a sufficiently organized nature to have spread some animals and lithics, notably obsidian, fairly widely (Anderson 2000; White 2004). A bamboo raft, coasting along the Phillipines, might have been taken to the Yaeyamas in the Kuroshio Current. In any event, an analogy can be found in the existence of ground Tridacna shell adzes in Yaeyamas sites. They are unique in Japan and are thought to represent late Holocene contact with western Oceania through the agency of the Kuroshio Current (Asato 1990, 1991).

\section{CONCLUSIONS}

The axe recovered at Nakano on Iriomote Island is a very distinctive item. In plan shape, it resembles other waisted artifacts which are common in the region, both in the Ryukyus and Taiwan to either side of Yaeyama archipelago, and to some extent within collections from the colonizing Shimotabaru phase, beginning about 3800 B.P. within the Yaeyamas. However, the resemblance is superficial. It is important to emphasize that the Iriomote specimen had been flaked and ground to form a sharp-edged axe. It is not just another notched or waisted implement, nor another ground stone implement without butt modification.

As a ground, waisted axe it has no reported parallel in the archaeology of Japan or Taiwan. The nearest artifacts of this type are to the south, in Near Oceania, where their history extends into the Pleistocene-Holocene transition. On the ground of the absence of this form in the known archaeology of the Yaeyamas and its neighboring archipelagos, we are inclined to regard the Iriomote axe as older than of Shimotabaru provenance. This is not a strong conclusion, although 
it is one that opens some important questions about the age and origins of island settlement in the region and it is, in principle, rather easy to overturn. If it should prove valid then it would add to increasing evidence of offshore seafaring (passages of greater than $50 \mathrm{~km}$ in open water) having a history extending back to the late Pleistocene in the western Pacific, both in Near Oceania and Japan (O'Connor and Veth 2000). In Japan, the evidence refers to procurement of obsidian from Kozushima Island, Honshu, about 21,000 B.P. and to human remains dated to 15,000-32,000 in the northern Ryukyu Islands (Matsu'ura 1996; Oda 1990). Given that such activity was occurring in both the northern and southern archipelagos of the west Pacific offshore island chain, and noting (above) a suggestion of contact between west Oceania and the Yaeyamas in the mid-Holocene, it would not be surprising to find that there had been a longstanding, if infrequently traveled, route of passage that traversed the Yaeyamas. Nevertheless, the strong conclusion to be drawn is that we may not yet know enough of the early human history of the region to be at all sure about the current archaeological sequences. Field research at the Nakano site is much to be desired but, so far at least, it has proven difficult to arrange.

\section{ACKNOWLEDGMENTS}

We thank Dr. Rintaro Ono, Professor Peter Matthews, and Ms. Ayako Shibutani (National Museum of Ethnology of Japan, Osaka), and Dr. Leo Aoi Hosoya (Waseda University), who worked with us in the Yaeyamas, and Mr. Nakamori, Archaeologist for the Taketomi Board of Education, who showed us the archaeological sites of Iriomote and gave permission to publish a report on the axe. We also appreciate the help of Mr. Asato (Okinawan Archaeological Board) and Mr. Mori Moto (Education Board of Okinawa) for facilitating our research. We worked in the Yaeyamas as Visiting Fellows at the Centre of Asian and Pacific Studies, University of the Ryukyus, and thank the Centre Director, Professor Oshiro, and the Vice President of the University, Professor Hiroshi Kakazu, for their assistance and hospitality. Discussions with Professor Takahashi (Waseda University), and Professor Liu (Academia Sinica, Taipei), and with Yaeyama archaeologists Ms. Ayano Shimabukuro and Mr. Ohama, provided valuable comparative information. We thank Emeritus-Professor Jack Golson (ANU) who kindly read and commented usefully on the manuscript. Lastly, warm thanks to Peter Matthews for his drawings, Ms. Hsiao-chun Hung, ANU, for searching and discussing the relevant Taiwanese literature, and Mrs. Rieko Hayakawa for invaluable help making the fieldwork possible, comfortable, and congenial.

\section{REFERENCES CITED}

Anderson, A. J.

2000 Slow boats from China: Issues in the prehistory of Indo-Pacific seafaring, in East of Wallace's Line: Studies of past and present maritime cultures of the Indo-Pacific region: 13-50, ed. S. O'Connor and P. Veth. Rotterdam: Balkema.

Asato, S.

1990 The distribution of shell adzes in the south Ryukyu Island, in The Urasoko site: $A$ sketch of the excavation in photographs: 29-39. The Gusukube Town Board of Education, Okinawa.

1991 Tridacna adzes in the Ryukyu Islands. Bulletin of the Indo-Pacific Prehistory Association $11: 282-291$

BeLLWOOd, P.

1997 Prehistory of the Indo-Malaysian archipelago. Revised ed. Honolulu: University of Hawai' $\mathrm{i}$ Press. 
Bellwood, P., J. Stevenson, A. Anderson, and E. Dizon

2003 Archaeological and palaeoenvironmental research in Batanes and Ilocos Norte Provinces, Northern Philippines. Bulletin of the Indo-Pacific Prehistory' Association 23:141-160.

BULmer, S.

1977 Waisted blades and axes: A functional interpretation of some early stone tools from Papua New Guinea, in Stone tools as cultural markers: Change, evolution and complexity: 40-59, ed. R.S.V. Wright. Canberra: Australian Institute of Aborigine Studies.

2005 Reflections in stone: Axes and the beginnings of agriculture in the central highlands of New Guinea, in Papuan pasts: Cultural, linguistic and biological histories of Papuan-speaking peoples: 387-450, ed. A. Pawley, R. Attenborough, J. Golson, and R. Hide. Canberra: Pacific Linguistics 572, Australian National University.

ESAKA, T.

1986 The origins and characteristics of Jomon ceramic culture: A brief introduction, in Windows on the Japanese past: Studies in archaeology and prehistory: 223-228, ed. R. Pearson, G. Barnes, and K. L. Hutterer. Ann Arbor: Center for Japanese Studies, University of Michigan.

Fairbairn, A., G. S. Hope, and G. R. Summerhayes

2006 Pleistocene occupation of New Guinea's highland and subalpine environments. World Archaeology 38:371-386.

FosTeR, H. L.

1956 Geology of Ishigaki-shima Ryukyu-retto. Geological Survey Professional Paper 399-A, Washington, D.C.: U.S. Department of the Interior. U.S. Government Printing Office.

\section{Golson, J.}

1974 Both sides of the Wallace Line: New Guinea, Australia, Island Melanesia and Asian Prehistory, in Early Chinese art and its possible influence in the Pacific Basin: 533-595, ed. N. Barnard. New York: Intercultural Press.

2001 New Guinea, Australia and the Sahul connection, in Histories of old ages: Essays in honour of Rhys Jones: 185-210, ed. A. Anderson, I. Lilley, and S. O'Connor. Canberra: Pandanus Books, Research School of Pacific and Asian Studies, Australian National University.

2005 The middle reaches of New Guinea history, in Papuan pasts: Cultural, linguistic and biological histories of Papuan-speaking peoples: 451-492, ed. A. Pawley, R. Attenborough, J. Golson, and R. Hide. Canberra: Pacific Linguistics 572, Australian National University.

Groube, L.

1984 Waisted axes of Asia, Melanesia and Australia, in Archaeology at ANZAAS Canberra: 168177, ed. G. Ward. Canberra: Canberra Archaeological Society Inc., Department of Prehistory and Anthropology, Australian National University.

1989 The taming of the rain forests: A model for late Pleistocene forest exploitation in New Guinea, in Foraging and farming: The evolution of plant exploitation: 292-304, ed. D. R. Harris and G. C. Hillman. London: Unwin Hyman.

Groube, L., J. Chappell, J. Muke, and D. Price

1986 A 40,000 year old occupation site at Huon Peninsula, Papua New Guinea. Nature $324: 453-455$.

HAYDEN, B.

1979 Palaeolithic reflections: Lithic technology and ethnographic excavations among Australian Aborigines. Canberra: Australian Institute of Aboriginal Studies.

IKaWA-Smith, F.

1986 Late Pleistocene and early Holocene technologies, in Windows on the Japanese past: Studies in archaeology and prehistory: 199-218, ed. R. Pearson, G. Barnes, and K. L. Hutterer. Ann Arbor: Center for Japanese Studies, University of Michigan.

IMAMURA, K.

1996 Prehistoric Japan: New perspectives on insular East Asia. Honolulu: University of Hawai'i Press.

INADA, T.

1987 The Palaeolithic Age, in Recent archaeological discoveries in Japan: 5-23, ed. K. Tsuboi and G. L. Barnes. Tokyo: The Centre for East Asian Cultural Studies.

Ishigaki Town Education Board

1982 Otabaru archaeological site excavation research report. Ishigaki Cultural Heritage Research Report No. 4 (in Japanese). 
1997 Nakura shell mound and Pyutsuta Archaeological Site Excavation Research Report. Ishigaki Educational Board (in Japanese).

ITO, S.

2003 The position of the Ryukyu Jomon culture in the Asia-Pacific region. Bulletin of the IndoPacific Prehistory Association 23:63-72.

Kanaseki, T., N. Kokubu, S. Tawada, and M. Nagai

1964 Archaeological survey at the Shimotabaru site in the island of Hateruma, Ryukyu, in 1954. Contribution from the Shimonoseki University of Fisheries 426:1-13 (in Japanese).

Kimura, M.

2000 Palaeogeography of the Ryukyu Islands. Tropics 10:5-24.

KокивU, N.

1963 The prehistoric Southern Islands and East China Sea Areas. Asian Perspectives 7:224-242.

LAMPERT, R.

1975 A preliminary report on some waisted blades found on Kangaroo Island, South Australia. Australian Archaeology 2:45-48.

LEACH, E.

1938 Stone implements from Botel Tobago Island. Man 38:161-163.

Matsu'ura, S.

1996 A chronological review of Pleistocene human remains from the Japanese archipelago, in Interdisciplinary perspectives on the origins of the Japanese: 181-197, ed. K. Omoto. Kyoto: International Research Centre for Japanese Studies.

McCarthy, F. D.

1967 Australian Aboriginal stone implements. Sydney: The Australian Museum.

Morwood, M., And P. J. Trezise

1989 Edge-ground axes in Pleistocene greater Australia: New evidence from S. E. Cape York Peninsula. Queensland Archaeological Research 6:77-90.

MоTOKAwa, M.

2000 Biogeography of living mammals in the Ryukyu Islands. Tropics 10:63-71.

National Museum of Prehistory

2004 Collecting the past. Taipei, National Museum of Prehistory.

Nishimura, M., T. Tamaguchi, K. Ohkawa, and A. Hamana

1960 Archaeology of Yaeyama, in Okinawa Yaeyama (Waseda Report): 113-216, ed. Hiroshi Takiguchi. Ko-so shobo (in Japanese).

O'ConNor, S.

199930,000 years of aboriginal occupation: Kimberley, North West Australia. Terra Australis 14. Canberra: The Centre for Archaeological Research, Australian National University.

O'CONNOR, S., AND P. VETH, EDS.

2000 East of Wallace's Line: Studies of past and present maritime cultures of the Indo-Pacific region. Rotterdam: Balkema.

ODA, S.

1990 A review of archaeological research in the Izu and Ogasawara Islands. Man and Culture in Oceania 6:53-79.

Oda, S. and C. T. Keally

1973 Edge-ground stone tools from the Japanese preceramic culture. Busshitsu Bunka (Material Culture) 22. Tokyo: The Study of Material Cultures.

OHAMA, E.

1999 Yaeyama no kokogaku (Archaeology of Yaeyama). Ishigaki. Sakishima Bunka Kenkyusho (in Japanese).

2002 Yaeyama no kokogaku (Archaeology of Yaeyama). Kokogaku Janaru 493:3 (in Japanese).

Okamura, $\mathrm{M}$.

1992 The achievements of research into the Japanese Palaeolithic. Acta Asiatica 63:21-39.

Okinawa Prefectural Board

1986 Shimotabarm Shell Mound and Ohdomarihama Shell Mound: 1st, 2nd, and 3rd fieldseason of excavations. Okinawa Prefecture Cultural Heritage Research Report No. 74 (in Japanese). 
Okinawa Prefectural Tarama-Village Education Board

1996 Taramasoedo archaeological site. Report of excavation research (in Japanese).

Otsuka, H., and A. TAKahashi

2000 Pleistocene vertebrate faunas in the Ryukyu Islands: their migration and extinction. Tropics $10: 25-40$.

SCHRIRE, C.

1982 The Alligator Rivers: Prehistory and ecology in western Arnhem Land. Terra Australis 7. Canberra: Department of Prehistory, Research School of Pacific Studies, Australian National University.

SHI, T.-F., LIU, L.-C., AND M.-C. YeH

2001 History of Taitung county - the prehistory. Taidong: Taidong County Government (in Chinese).

Serizawa, C.

1986 The Paleolithic Age of Japan in the context of East Asia: A brief introduction, in Windows on the Japanese past: Studies in archaeology and prehistory: 191-198, ed. R. Pearson, G. Barnes, and K. L. Hutterer. Ann Arbor: Center for Japanese Studies, University of Michigan.

Summerhayes, G. R., A. Anderson, S. Asato, L. Hosoya, R. Ono, and S. Shimogi

n.d. Shimotabaru pottery, the Yaeyama Islands, and their relationship to the Austronesian expansions out of Taiwan at 4,000 years ago. Unpublished paper.

Sung, W.-H., AND C.-M. Lien

2004 Peinan excavations 1980-1982. Analytical studies on the stratified sequence and the culture remains from habitation levels. Taipei: National Taiwan University Press (in Chinese).

UJIIE, H., AND Y. UJIIE

1999 Late Quaternary course changes of the Kuroshio Current in the Ryukyu arc region, northwestern Pacific Ocean. Marine Micropalaeontology 37:23-40.

Wang, C.-N., M. Möller, And Q.C.B. Cronk

2004 Population genetic structure of Titanotrichum oldhami (Gesneriaceae), a subtropical bulbiliferous plant with mixed sexual and asexual reproduction. Annals of Botany 93: 201-209.

WHITE, J. P.

2004 Where the wild things are: Prehistoric animal translocation in the circum New Guinea archipelago, in Voyages of discovery: The archaeology of islands: 147-164, ed. S. M. Fitzpatrick. Westport, CT: Praeger.

White, J. P., K.A.W. Crook, And B. P. Ruxton

1970 Kosipe: A late Pleistocene site in the Papuan highlands. Proceedings of the Prehistoric Society $36: 152-170$.

ZhaO, C., X. Wu, T. WANG, AND X. YUAN

2004 Early polished stone tools in South China evidence of the transition from Palaeolithic to Neolithic. Documenta Praehistorica 31:131-137.

\begin{abstract}
A flaked, ground, and waisted axe, discovered on Iriomote Island in the Yaeyama group, southernmost Japan, appears to be a unique find in Japanese prehistory. Its resemblance to waisted, edge-ground axes which, in Australia, are of Pleistocene age, and to similar artifacts of early Holocene age in New Guinea, as well as potential antecedents in the Pleistocene edge-ground axes of Honshu, invites questions about its significance. This is especially so because the Yaeyama Islands are regarded currently as having been first occupied by people during the Shimotabaru phase of Neolithic culture, beginning about 3800 B.P. Comparison with similar western $\mathrm{Pa}$ cific artifacts, and consideration of the eustatic history of the Yaeyamas, suggest that the Iriomote example might be of early Holocene age, although its origin within the late Holocene cannot be excluded. The find raises questions about the human history of the southern Ryukyu groups that demand further research. Keywords: Yaeyama Islands, Japan, polished waisted axe, Holocene colonization.
\end{abstract}

